\title{
ANALISIS PROSPEKTIF PILKADA PASCA PUTUSAN \\ GUGATAN DI MAHKAMAH KONSTITUSI \\ (Studi Kasus Pemilihan Bupati dan Wakil Bupati \\ di Kabupaten Jepara dan Pati)
}

\section{Ris Andy Kusuma, Subarkah dan Suparnyo}

Email : ris.andi.os@gmail.com, subarkah_sh@yahoo.com, suparnyo@umk.ac.id

Fakultas Hukum Universitas Muria Kudus

\begin{abstract}
ABSTRAK
Pelaksanaan Pemilihan Kepala Daerah (Pilkada) serentak di Kabupaten Jepara dan Pati telah usai. Hasilnya pasangan calon yang kalah di Kabupaten Jepara mengajukan proses permohonan pembatalan Penetapan Perolehan Suara Pemilihan Bupati dan Wakil Bupati Jepara di Mahkamah Konstitusi (MK). Relawan kotak kosong di Kabupaten Pati juga sama mengajukan permohonan pembatalan Penetapan Perolehan Suara Pemilihan Bupati dan Wakil Bupati Pati di MK. Untuk itu, penelitian ini mendeskrispsikan proses munculnya permohonan dan proses pengajuan permohonan serta menganalisa prospektif pasca putusan permohonan Perselisihan Hasil Pemilu (PHP) di MK untuk mendukung proses demokratisasi. Pendekatan penelitian ini adalah yuridis empiris, yaitu dengan menganalisis permasalahan dengan cara memadukan bahan-bahan hukum dengan data primer yang diperoleh di lapangan. Sasaran penelitian adalah komisioner KPU, komisioner Bawaslu, pasangan calon bupati dan wakil bupati, anggota tim sukses, pengurus partai politik pengusung, dan relawan Kotak Kosong.
\end{abstract}

Kata Kunci : Permohonan, Pilkada, Prospektif 


\section{PENDAHULUAN}

Rezim otoriter telah runtuh sejak reformasi 1998 lalu. Demokratisasi yang dijalankan. Kini telah berjalan baik di Indonesia. Terutama, dalam memilih pemimpin. Masyarakat dapat memilih calon pemimpin sendiri sesuai suara hati, tanpa ada paksaan atau intervensi dari pihak manapun. Pemimpin tidak lagi berdasarkan keturunan.

Proses pemilihan dari masyarakat ini diyakini menghasilkan pemerintahan yang demokratis. Pemerintahan milik semua orang, bukan pemerintahan satu orang (autocracy). Jalan pemerintahannya juga diharapkan lebih terbuka, lebih responsif, dan melaksanakan aspirasi masyarakat. Nantinya dapat mewujudkan pemerintahan dari rakyat, oleh rakyat, dan untuk rakyat.

Penerapan sistem ini akan membuat masyarakat mendapatkan penghargaan yang lebih tinggi dalam pemerintahan. Posisi yang tinggi menurut Alcein "vox populi, vox dei (suara rakyat adalah suara Tuhan)", sedangkan menurut Machiavelli "publica voce". 1 Suara rakyat bisa dalam bentuk memberikan aspirasi, masukan atau kritik atas penyelenggaraan pemerintahan.

Partisipasi masyarakat ini diawali dari memilih calon pemimpin. Pemilihan ini seperti yang tertuang dalam sila keempat Pancasila, "Kerakyatan yang dipimpin oleh hikmat kebijaksanaan dalam permusyawaratan dan perwakilan". Muaranya untuk mewujudkan kedaulatan rakyat.

\footnotetext{
1 Wayne Parson, "Public Policy: Pengantar Teori dan Praktik Analisis Kebijakan", Penerjemah Tri Wibowo Budi Santoso, Kencana, Jakarta, 2005, hal. 113
}

Pemilihan secara langsung juga tercermin dalam pasal 1 ayat 2 UndangUndang Dasar 1945 yang menyatakan bahwa kedaulatan berada di tangan rakyat. Untuk pemilihan bupati dan wakil bupati tertuang dalam pasal 18 ayat 4 Undang-Undang Dasar 1945, "Gubernur, Bupati, dan Walikota masing-masing sebagai kepala pemerintah daerah provinsi, kabupaten dan kota dipilih secara demokratis". Pemilihannya dilakukan secara langsung oleh masyarakat. Pelaksanaannya diatur dalam UndangUndang Nomor 10 Tahun 2016 tentang Pilkada. Berbeda dengan Pilkada sebelumnya, pemilihan bupati dilakukan oleh anggota Dewan Perwakilan Rakyat Daerah (DPRD). Saat itu rakyat menjadi objek, kini telah menjadi subjek. Masyarakat dapat berpartisipasi aktif sehingga memunculkan karakter demokrasi.

Pemilihan bupati melalui Pilkada di Kabupaten Jepara dan Pati secara langsung sudah dua kali terjadi. Kali pertama untuk Kabupaten Jepara pada 2011 dan Kabupaten Pati 2012. Meski berbeda di periode pertama, tetapi pilkada kedua di dua kabupaten ini dibarengkan di Pilkada Serentak 2017. Pilkada ini telah usai. Meski Pemilihan Bupati Pati dan Jepara telah selesai, di pelaksanaannya sempat menyisakan ketidakpuasan dari calon bupati atau perwakilan masyarakat atas hasil Pilkada.

Seusai penetapan pasangan calon yang memperoleh suara terbanyak oleh Komisi Pemilihan Umum (KPU), pasangan calon bupati yang meraih suara yang kalah di Kabupaten Jepara mengajukan gugatan atau permohonan ke Mahkamah Konstitusi (MK). Begitu juga perwakilan masyarakat di 
Kabupaten Pati mengajukan gugatan atau permohonan ke MK. Kedua pihak yang kalah itu merasa ada dugaan ketidakberesan secara sistematis dalam pelaksanaan hingga penetapan hasil Pilkada.

Berdasarkan hasil pemunggutan suara yang dilakukan KPU Kabupaten Pati di Pilkada Pati, pasangan HaryantoSaiful Arifin meraih 519.675 suara atau 75 persen suara dari total 697.437 suara sah. Pasangan yang didukung delapan partai politik ini tidak memiliki lawan pasangan. Lawannya, hanya kotak kosong. Namun, kotak ini mampu memperoleh dukungan sekitar 25 suara atau 177.762 suara.

Kemenangan yang diraih pasangan Haryanto-Saiful Arifin tidak berjalan mulus. Seusai perhitungan KPU manual relawan kotak kosong yang tergabung Aliansi Kawal Demokrasi Pilkada Pati (AKDPP) mengajukan permohonan ke MK. Gugatan ini teregister di MK dengan Nomor: $\quad 41 /$ PHP.BUP-XV/2017. ${ }^{2}$ Mereka menggandengan aktivis Kontras Haris Azhar sebagai kuasa hukum.

Gugatan ini diajukan karena menemukan dugaan pelanggaran HAM dan politik uang yang terstruktur dan masif oleh paslon serta beberapa pelanggaran yang dilakukan oleh penyelenggara pilkada. $^{3}$ Gugatan AKDPP terhadap perselisihan hasil pemilu (PHP) ini ada tiga hal penting yang masuk dalam materi. Kajian itu menyangkut legal standing pemohon, tenggat waktu pengajuan permohonan,

\footnotetext{
${ }^{2}$ Http://jateng.tribunnews.com/2017/03/16/meng ejutkan-ini-alasan-relawan-kotak-kosongajukan-gugatan-ke-mk-terkait-hasil-pilkadapati-2017, 10 Agustus 2017

${ }^{3}$ Http://seputarmuria.com/2017/03/13/gugatanrelawan-kotak-kosong-diregistrasi-mk/,10 Agustus 2017
}

dan ambang batas selisih hasil perolehan suara yang dipersyaratkan di kabupaten/kota.

Berdasarkan latar belakang permasalahan yang ada tersebut, maka penulis memberikan judul dalam penelitian ini "Analisis Prospektif Pilkada Pasca Putusan Gugatan Perselisihan Hasil Pemilu (PHP) di Mahkamah Konstitusi (Studi Kasus Pemilihan Bupati dan Wakil Bupati di Kabupaten Jepara dan Pati)." Maka penulis merumuskan permasalahan sebagai berikut :

1. Mengapa terjadi gugatan Perselisihan Hasil Pemilu (PHP) Pilkada di MK dari pasangan calon yang kalah di Kabupaten Jepara dan relawan kotak kosong di Kabupaten Pati?

2. Mengapa Para Pengugat mengajukan gugatan atas Perselisihan Hasil Pemilu (PHP) Pilkada Jepara dan Pati di MK?

3. Bagaimana analisis prospektif Para Pengugat pasca putusan gugatan Perselisihan Hasil Pemilu (PHP) di MK untuk mendukung proses demokratisasi?

\section{METODE PENELITIAN}

Penelitian ini penulis menggunakan metode studi hukum, baik law in the books maupun law in action karena mempelajari dan meneliti hubungan timbal balik antara hukum dengan lembaga-lembaga sosial yang lain terhadap hukum sebagai law in action. Penelitian ini merupakan studi ilmu sosial yang non-doktrinal dan bersifat empiris.

Model yang digunakan adalah analisis interaktif menurut Miles dan Huberman ada tiga komponen analisis, yaitu reduksi data, sajian data, dan penarikan kesimpulan atau verifikasinya 
dalam bentuk interaktif dengan pengumpulan data sebagai suatu siklus. Bentuk penelitian ini bergerak diantara tiga komponen utama analisis dengan proses pengumpulan data selama kegiatan pengumpulan data berlangsung. Pengumpulan data berakhir, peneliti tetap bergerak diantara tiga komponen utama analisis dengan menggunakan waktu tersisa dalam penelitian.

\section{HASIL PENELITIAN DAN PEMBAHASAN}

\section{Tinjauan tentang Pilkada}

Pemilihan kepala daerah (Pilkada) bertujuan untuk memilih pemimpin. Pemilihannya secara langsung yang dilakukan oleh rakyat dalam satu daerah. Pemimpin ini dipilih oleh penduduk setempat yang memenuhi syarat berdasarkan peraturan yang berlaku.

Pilkada ini untuk memilih gubernur dan wakil gubernur atau bupati/wali kota dan wakil bupati/wakil wali kota. Pemilihan ini tidak diatur dalam UUD 1945, tetapi oleh UU. Di antaranya UU Nomor 32 Tahun 2004, UU Nomor 22 Tahun 2007, dan UU Nomor 6 Tahun 2016. Pelaksanaannya diadakan setiap lima tahun sekali.

Pentingnya pemilihan ini, pertama, dengan Pilkada dimungkinkan untuk mendapatkan kepala daerah yang memiliki kualitas dan akuntabilitas. Kedua, Pilkada perlu dilakukan untuk menciptakan stabilitas politik dan efektivitas pemerintahan di tingkat lokal. Ketiga, dengan Pilkada terbuka kemungkinan untuk meningkatkan kualitas kepemimpinan nasional karena makin terbuka peluang bagi munculnya pemimpin-pemimpin nasional yang berasal dari bawah dan/atau daerah. ${ }^{4}$

Pemilihan umum ini sebagai momentum penting pembentukan pemerintahan dan penyelenggaraan pemerintahan periode berikutnya secara berkala. Pentingnya pilkada bagi penyelenggaraan negara yang demokratis dapat dilihat dari penegasan asas-asas pelaksanaan pemilu, yaitu langsung, umum, bebas, rahasia, jujur, dan adil.

\section{Gugatan}

Gugatan menurut Sudikno

Mertokusumo, tindakan yang bertujuan memperoleh perlindungan yang diberikan oleh pengadilan untuk mencegah main hakim sendiri (eigenrichting). Darwan Prinst, gugatan adalah suatu permohonan yang disampaikan kepada Ketua Pengadilan Negeri yang berwenang mengenai suatu tuntutan terhadap pihak lainnya dan harus diperiksa menurut tata cara tertentu oleh pengadilan serta kemudian diambil putusan terhadap gugatan tersebut. Cirinya, perselisihan hukum yang diajukan ke pengadilan mengandung sengketa yang terjadi diantara para pihak, paling kurang diantara dua pihak bersifat partai (party) dengan komposisi, pihak yang satu bertindak dan berkedudukan sebagai penggugat dan pihak lain berkedudukan sebagai tergugat. ${ }^{5}$

\section{Demokratisasi}

Demokrasi dalam bahasa Inggris democrazy, secara harfiah berasal dari

\footnotetext{
4 Syafran Sofyan, Permasalahan dan Solusi Pemilukada, http : //www.lemhannas.go.id/ portal/in/daftar-artikel/1634-permasalahandan-solusi-pemilukada.html, 20 September 2013.

${ }^{5} \mathrm{Http} / /$ upipagow.blogspot.co.id/2013/11/penger tian-dan-penjelasan-tentang.html, 6 Mei 2017
} 
bahasa Yunani, yaitu demos yang berarti rakyat dan kratia yang berarti pemerintahan. ${ }^{6} \quad$ Abraham Lincoln mendefinisikan demokrasi sebagai "government of the people, by the people, for the people", yaitu sistem pemerintahan atau kekuasaan dari rakyat, baik yang bersifat langsung maupun dengan sistem perwakilan. ${ }^{7}$

Joseph Schumpeter justru memandang dari sisi lain, demokrasi merupakan metode politik. ${ }^{8}$ Dahl juga memandang demokrasi sebagai sebuah sistem politik. ${ }^{9}$ Ghofur memiliki arti luas tentang demokrasi merupakan sebuah sistem politik dengan rakyat sebagai pemegang kekuasaan tertinggi atas pemerintahan di suatu negara, bukan raja, bukan negarawan, atau sekelompok elit-elit tertentu. Secara lebih tajam demokrasi sebagai bentuk pemerintahan dimana keputusankeputusan pemerintah yang penting atau arah kebijakan dibalik keputusan itu, secara langsung maupun tidak langsung yang didasarkan pada kesepakatan yang diberikan secara bebas dari rakyat dewasa. $^{10}$

\section{Kebijakan Publik}

Kebijakan dilihat secara filosofi sebagai suatu produk, sebagai suatu proses, dan suatu kerangka kerja. ${ }^{11}$ Sebagai konsep filosofis, kebijakan merupakan serangkaian prinsip

${ }^{6}$ Eddi Wibowo dan Hessel Nogi S. Tangkilisan, "Kebijakan Publik Pro Civil Society", YPAPI. Yogyakarta, 2004, hlm 13

${ }^{7}$ Ibid hlm 13

${ }^{8}$ Georg Sorensen, "Demokrasi dan Demokratisasi”, Penerjemah I Made Krisna, Pustaka Pelajar, Yogyakarta, 1993, hlm 14

${ }^{9}$ Ibid. hlm 18

${ }^{10}$ Georg Sorensen, "Demokrasi dan Demokratisasi”, Penerjemah I Made Krisna, Pustaka Pelajar, Yogyakarta, 1993, hlm 61

${ }^{11}$ Yerimias T Keban, "Enam Dimensi Strategi Administrasi Publik Konsep Teori dan Isu", Gava Media, Yogyakarta, 2004, hal 55 kesimpulan atau rekomendasi; sebagai suatu proses dipandang sebagai suatu cara dimana melalui cara tersebut suatu organisasi dapat mengetahui apa yang diharapkan darinya, yaitu program dan mekanisme dalam mencapai produknya; sebagai kerangka kerja, kebijakan merupakan suatu proses tawar menawar dan negosiasi untuk merumuskan isuisu dan metode implementasi.

Kebijakan dalam arti luas memiliki dua aspek penting, yaitu pertama, kebijakan merupakan praktika sosial, bukan event tunggal atau terisolir. Dengan demikian, segala sesuatu yang dihasilkan pemerintah berasal dari segala kejadian dalam masyarakat dan digunakan untuk kepentingan masyarakat. Kedua, kebijakan adalah suatu peristiwa yang ditimbulkan oleh baik untuk mendamaikan claim dari pihak-pihak yang konflik, atau untuk menciptakan incentive bagi tindakan bersama bagi pihak-pihak yang ikut menetapkan tujuan, akan tetapi mendapatkan perlakuan yang tidak rasional dalam usaha bersama tersebut. $^{12}$

Robert Eyestone mengatakan bahwa "secara luas" kebijakan publik dapat didefinisikan sebagai "hubungan suatu unit pemerintah dengan lingkungannya". Menurut Thomas R. Dye, kebijakan publik adalah apapun yang dipilih pemerintah untuk dilakukan atau tidak dilakukan. ${ }^{13}$ Sementara James Anderson, kebijakan sebagai arah tindakan yang mempunyai maksud yang ditetapkan oleh seorang aktor atau sejumlah aktor dalam

\footnotetext{
${ }^{12}$ Miftah Thoha, "Dimensi-Dimensi Prima Ilmu Administrasi Negara", PT. RajaGrafindo Persada, Jakarta, 2002, hal 59-60

13 Budi Winarno, "Teori dan Proses Kebijakan Publik", MedPress, Yogyajakarta, 2002, hal 15
} 
mengatasi suatu masalah atau suatu persolan. ${ }^{14}$ David Easton mengartikan bahwa kebijakan publik sebagai "The authoritative allocation of values for woles society" (pengalokasian nilai-nilai secara paksa/sah kepada seluruh anggota masyarakat). ${ }^{15}$

\section{Partisipasi Masyarakat}

Partisipasi sering diartikan dengan pembangunan masyarakat yang mandiri, perwakilan, mobilitas sosial, pembagian sosial yang merata terhadap hasil-hasil pembangunan, penetapan kelembagaan khusus, demokrasi politik dan sosial, reformasi sosial, atau bahkan yang disebut revolusi sosial. ${ }^{16}$ Mubyarto mendefinisikan partisipasi sebagai kesediaan untuk membantu berhasilnya setiap program sesuai kemampuan setiap orang tanpa berarti mengorbankan kepentingan diri sendiri. $^{17}$

Menurut World Bank, partisipasi sebagai keterlibatan masyarakat, dimaknai sebagai sebuah proses dimana para stakeholder saling mempengaruhi dan berbagai kontrol atas inisiatif pembangunan, keputusan dan juga sumber daya yang akan mempengaruhi mereka. ${ }^{18}$

PBB mendefinisikan partisipasi sebagai keterlibatan aktif dan bermakna

\footnotetext{
${ }^{14}$ Ibid. hal. 15

${ }^{15}$ M. Irfan Islamy, "Prinsip-Prinsip Perumusan Kebijaksanaan Negara”, PT Bumi Aksara, Jakarta, 2000, hal. 19

${ }^{16} \mathrm{Y}$. Slamet, "Pembangunan Masyarakat Berwawasan Partisipasi", Sebelas Maret University Press, Surakarta, 1993, hal. 1

${ }^{17}$ Taliziduhu Ndraha, "Pembangunan Masyarakat Mempersiapkan Masyarakat Tinggal Landas", Rineka Cipta, Yogyakarta, 1990, hal. 102

${ }^{18}$ Eddi Wibowo dan Hessel Nogi S Tangkilisan, "Kebijakan Publik Pro Civil Society", YPPAPI, Yogyakarta, 2004, hal. 52
}

dari masa penduduk pada tingkatantingkatan berbeda:

1. Dalam proses pembentukan keputusan untuk menetukan tujuan-tujuan kemasyarakatan dan pengalokasian sumber-sumber untuk mencapai tujuan-tujuan tersebut,

2. Pelaksanaan program-program dan proyek-proyek secara sukarela,

3. Pemanfaatan hasil-hasil dari suatu program atau suatu proyek. ${ }^{19}$

Perhatian utama dalam partisipasi masyarakat terletak pada tanggung jawab individu dan mempunyai lokus pada pengambilan keputusan atau kebijakan. Hal ini masyarakat yang berpartisipasi dipandang sebagai pihak yang berpengetahuan, berwawasan, cerdas, dan aktif jika kepada mereka diberikan kesempatan dalam keterlibatan masyarakat yang effektif. ${ }^{20}$ Masyarakat ditekankan untuk terlibat secara langsung maupun tidak langsung dalam proses pembangunan.

\section{Analisis Prospektif Pasca Gugatan Perselisihan Hasil Pemilu (PHP) pada Pilkada Jepara di MK}

Mahkamah Konstitusi (MK) telah memeriksa dan mengadili perkara perselisihan perolehan suara hasil pemilihan Calon Bupati dan Calon Wakil Bupati Kabupaten Jepara. Gugatan Subroro-Nur Yaman (Sulaiman) tidak memenuhi syarat. Amar putusan sengketa Pilkada Nomor 2/PHP.BUP.XV/2017 itu dibacakan Ketua MK Arif Hidayat didampingi delapan hakim MK lainnya. MK menilai Sulaiman tidak mempunyai

\footnotetext{
19 Y. Slamet, "Pembangunan Masyarakat Berwawasan Partisipasi", Sebelas Maret University Press, Surakarta, 1993, hal. 3

${ }^{20}$ Eddi Wibowo dan Hessel Nogi S Tangkilisan, "Kebijakan Publik Pro Civil Society", YPPAPI, Yogyakarta, 2004, hal 50
} 
kedudukan hukum untuk mengajukan sengketa sesuai ketentuan Pasal 158 Ayat (2) huruf d karena selisih suara sekitar 2,5 persen. Gugatan itu bisa dilakukan jika selisih suara maksimal 0,5 persen.

Putusan MK itu menguatkan SK KPU Jepara Nomor 36 tentang Penetapan Hasil Rekapitulasi Hasil Pilbup Jepara 2017.

Calon terpilih Ahmad MarzuqiDian Kristiandi pada Pilkada 2017 diusulkan ke DPRD Jepara. Melihat proses yang berkembang pelaksanaan Pilkada dibagi dalam lima tahapan. Di antaranya pendataan pemilih, penetapan calon, kampanye, pemungutan suara, dan hasil perhitungan suara.

\section{Tahapan Pendataan Pemilih}

Pemutakhiran data pemilih di setiap menjelang pemilihan umum menjadi persoalan. Data kependudukan yang dikeluarkan Kementerian Kependudukan melalui Dinas Kependudukan ditengarai menimbulkan permasalahan. Di antaranya masih tidak tercatatnya perpindahan penduduk dan pertumbuhan penduduk.

Kondisi itu berpengaruh terhadap data pemilih tetap (DPT). Penentuan DPT ini melalui berbagai tahapan. Data kependudukan diserahkan kepada KPU. Selepas itu data diverifikasi oleh petugas pemutakhiran pemilih (pantarlih). Petugas mendatangi pemilih yang berada di wilayahnya masingmasing.

Saat proses verifikasi itu ditemukan masih banyak masyarakat yang belum melakukan perekaman eKTP. Minimnya kesadaran melakukan perekaman e-KTP menjadi salah satu sebab. Meski pemerintah sudah melakukan jemput bola perekaman eKTP. Tetapi, masyarakat masih enggan menggurus

karena

belum membutuhkan. Banyaknya masyarakat boro atau bekerja di luar kota juga menjadi kendala dalam perekaman eKTP.

Dalam kurun waktu tertentu juga ada warga yang pindah alamat. Ada juga yang pernikahan meski usianya belum mencapai 17 tahun. Perpindahan penduduk ini tidak tercatat rapi mulai di tingkat RT. Tidak ada pencatatan ini berpengaruh proses pendataan penduduk di tingkat desa. Data yang berada di kecamatan juga terpengaruh dari desa. Begitu juga dengan data di tingkat kabupaten, terpengaruh data dari kecamatan.

Tidak sistematisnya pencatatan ini berdampak adanya pemilih ganda atau tidak ditemukannya alamat pemilih. Masyarakat yang sudah meninggal tidak dicatat dengan rapi. Warga tersebut masih tercatat hidup dalam data kependudukan. Terutama, ahli waris atau keluarga yang malas mengurus akta kematian. Begitu juga masyarakat yang telah berusia 17 tahun. Minimnya kesadaran remaja melaporkan usianya telah berusia 17 tahun. Orang tua juga terkadang tidak menyadari mempunyai anak telah berusia 17 tahun saat diadakan pemilihan umum atau Pilkada. Kondisi itu membuat pengurus RT atau desa tidak banyak yang mengetahui tentang pertambahan atau pertumbuhan warga yang telah berusia 17 tahun.

Persoalan lain warga yang belum 17 tahun sudah menikah. Peristiwa ini juga tidak tercatat di tingkat paling bawah. Kondisi itu mengakibatkan warga tersebut bisa saja kehilangan hak pilih. Kejadian itu membuat ada kartu undangan untuk pemilih yang dikembalikan kepada KPU. Karena alamat pemilihnya tidak jelas, 
meninggal dunia, nama sesuai, pemiliknya sudah pindah.

Kelemahan ini berpotensi menimbulkan gugatan dari pasangan calon. Karena merasa dirugikan dengan pendataan pemilih. Padahal, pemilih ini berpotensi memilih pasangan calon tersebut. Terutama, setelah perhitungan suara dan hasilnya selisih sedikit. KPU telah melakukan pemutakhiran data pemilih. Data yang diberikan oleh dinas kependudukan dikrocek oleh KPPS. Petugas mengecek kebenarannya data pemilih. Sebab data yang diambil beberapa bulan sebelumnya.

Dalam rentan waktu itu tentu ada penduduk yang menikah, meninggal dunia, dan pindah alamat. Pemuktahiran ini merupakan tahapan krusial dalam penyelenggaraan pilkada. Permasalahan ini tak pernah kunjung usai. Problem yang sering kali muncul di antaranya Petugas Pemutakhiran Data Pemilih (PPDP) tidak melakukan pencocokan dan penelitian (coklit) atau coklit dilakukan oknum lain yang tidak tercantum dalam surat keputusan KPU. Selain itu, petugas pemuktahiran tidak mencoret pemilih yang sudah tidak memenuhi syarat dan tidak mencatat pemilih yang memenuhi syarat untuk terdaftar di DPT.

Syarat pemilih menurut PKPU Nomor 2 Tahun 2017 Pasal 5 ayat 2 adalah genap berumur 17 tahun atau lebih pada hari pemungutan suara atau sudah/pernah kawin, tidak sedang terganggu jiwa/ingatannya, tidak sedang dicabut hak pilihnya berdasarkan putusan pengadilan yang mempunyai ketetapan hukum tetap, berdomisili di daerah pemilihan Yang dibuktikan dengan KTP elektronik (e-KTP), dalam hal pemilih tidak belum memiliki eKTP dapat menggunakan surat keterangan yang diterbitkan dinas yang menyelenggarakan urusan kependudukan dan pencatatan sipil setempat serta tidak sedang menjadi anggota TNI/Polri. "Penyelesaian persoalan pendataan penduduk yang dilakukan pemerintah. Sampai saat ini perekaman e-KTP belum juga selesai." ${ }^{21}$

Pemutakhiran data ini dimulai penyerahan Daftar Penduduk Potensial Pemilih Pemilu (DP4) dari pemerintah kepada KPU. Daftar pemilih dimutakhirkan dan diumumkan secara luas oleh PPS. Hal ini untuk menentukan Daftar Pemilih Sementara (DPS). Jumlah itu untuk menentukan jumlah tempat pemungutan suara (TPS). Selepas itu, data dikroscek untuk menjadi DPT. "Untuk itu perlu solusi pendataan pemilih dari pemerintah. Terkesan up date pendataan saat menjelang pemilihan umum.",22

\section{Kesimpulan}

1. Gelombang demokratisasi di Indonesia tidak terbendung lagi. Pemilihan bupati dan wakil bupati tidak lagi melalui DPRD melainkan secara langsung. Sayangnya hasil pilkada tidak bisa diterima dengan lapang dada. Hal itu didasari atas ketidakpuasan atas hasil perolehan suara dari pemilihan kepala daerah. Pemohon berusaha mencari celah untuk mengajukan gugatan di MK. Bukti dan argumentasi telah disiapkan meski ada aturan pengajuan gugatan di MK.

2. Proses pengajuan permohonan dari pemohon tidak mudah. Mereka

\footnotetext{
${ }^{21} \mathrm{Sz}$, "Wawancara Pribadi", Komisioner KPU Jepara, 6 Agustus 2018

22 Ol, "Wawancara Pribadi", Anggota Panwaslu Jepara, 10 Agustus 2018
} 
sudah mengetahui pemohonan itu telah diatur dalam UU Nomor 10 Tahun 2016 dan PMK. Adanya aturan ini sebagai mengakomodasi pasangan calon yang kalah atau pemantau resmi mengajukan permohonan atas ketidakpuasan. Apa yang diajukan oleh pemohon tidak sesuai dengan kondisi yang lapangan, sehingga pengajuan pembatalan penetapan perolehan hasil suara dalam Pilkada Jepara dan Pati tidak bisa diterima oleh MK. Putusan majelis hakim MK sudah memutuskan permohonan pembatalan penetapan hasil perolehan suara tidak diterima. Keputusan itu mengikat. Kedua pemohon, termohon, dan pihak memiliki harapan akan pilkada di masa mendatang. Terutama memperbaiki dugaan pelanggaraan yang diajukan oleh pemohon, mulai pendataan pemilih hingga penetapan perolehan suara. Agar pilkada yang sudah baik ini bisa menjadi lebih baik lagi karena pilkada yang digelar telah mengeluarkan anggaran yang besar. Pemilihan bupati dan wakil bupati diharapkan mampu menghasilkan pemimpinan yang berkualitas.

\section{Saran}

\section{Pemilihan}

Kesadaran data kependudukan masih rendah. Masih banyak warga yang enggan melaporkan perubahan data perpindahan atau ada anggota keluarga yang berusia 17 tahun, menikah, dan meninggal dunia. Begitu juga melakukan perekaman e-KTP. Padahal, pemerintah sudah melakukan jemput bola dan pelayanan sudah didekatkan dengan tempat tinggal warga. Sehingga perlu ada dorongan peningkatan kesadaran untuk melaporkan perubahan kependudukan dan melakukan perekaman e-KTP.

2. Peserta Pemilihan

Pemilihan Bupati dan Wakil Bupati ibarat sebagai kompetisi. Ada yang memperoleh suara terbanyak. Hal itu patut disadari dari awal sehingga mampu menerima kekalahan dengan lapangan dada tanpa perlu mencari kesalahan-kesalahan dari pihak lain.

3. Penyelenggara Pemilihan

Tertib administrasi dan melaksanakan tahapan demi tahapan pilkada dengan transparan sudah dilakukan dengan baik oleh penyelenggara. Kondisi ini jangan sampai lengah karena bisa menjadi polemik dalam pelaksanaan Pilkada.

\section{Pengawas Pilkada}

Praktik kecurangan dalam proses Pilkada bisa diantipasi bersama. Sehingga rasa tidak puas atas proses pelaksanaan Pilkada mampu ditekan. Untuk itu, lembaga pengawas atau pemantau melakukan pengawasan dengan maksimal. Pengawas ini diharapkan mampu bertindak tegas dengan dilandasi peraturan yang berlaku atas laporan dari masyarakat atau hasil temuan.

\section{Kelompok masyarakat}

Pelaksanaan pilkada tidak bisa lepas dari peran serta kelompok masyarakat, baik yang bersifat golongan, agama atau kedaerahan. Sepanjang memiliki kepentingan yang positif, kelompok tersebut sebaiknya mendaftarkan dulu kepada lembaga pemerintahan atau KPU. Agar bisa berperan aktif dalam pelaksanaan pilkada tanpa melanggar peraturan perundang-undangan yang berlaku. 


\section{DAFTAR PUSTAKA}

Islamy, M. Irfan. 2000. Prinsip-Prinsip Perumusan Kebijaksanaan

Negara. Cetakan Ke-6. PT Bumi Aksara Jakarta

Keban, Yeremias T. 2004. Enam Dimensi Strategis Administrasi Publik Konsep, Teori dan Isu. Gava Media. Yogyakarta

Ndraha, $\quad$ Taliziduhu. 1990. Pembangunan Masyarakat Mempersiapkan Masyarakat Tinggal Landas. Cetakan ke-2. Rineka Cipta. Yogyakarta.

Parsons, Wayne. 2005. Public policy: Pengantar Teori dan Praktik Anlisis Kebijakan. Penerjemah Tri
Wibowo Budi santoso. Kencana. Jakarta.

Slamet, Y. 1993. Pembangunan Masyarakat Berwawasan Partisipasi. Sebelas Maret University Press. Surakarta.

Sorensen, Georg. 1993. Demokrasi dan Demokratisasi. Penerjemah I made Krisna. Pustaka Pelajar. Yogyakarta.

Thoha, Miftah. 2002. Dimensi-Dimensi Prima Ilmu Administrasi Negara. Cetakan ke-6. PT RajaGrafindo Persada. Jakarta.

Winarno, Budi. 2002. Teori dan Proses Kebijakan Publik. MedPress. Yogyakarta 